\title{
Locating Power and Decision-Making: Social Production of Space in Juiz de Fora, Brazil
}

Victor Nascimento ${ }^{1}$, Carina Cardoso ${ }^{2,3}$, Marcelo Ribeiro Tavares ${ }^{4}$, Mariane Garicia Unanue ${ }^{5}$, Patricia Maya-Monteiro $^{6}$, Frederico Braida ${ }^{7}$ and Antonio Colchete Filho ${ }^{8}$

1. Department of Design, History and Theory, Federal University of Juiz de Fora, Juiz de Fora, 36036-900, Brazil;

2. Graduate Program in Urbanism, Federal University of Rio de Janeiro, Rio de Janeiro, 21941-901, Brazil;

3. Department of Architecture and Urbanism, Federal University of Goiás, Goiás, 76600-000, Brazil;

4. Graduate Program in Urbanism, Federal University of Rio de Janeiro, Rio de Janeiro, 21941-901, Brazil;

5. Department of Design, History and Theory, Federal University of Juiz de Fora, Juiz de Fora, 36036-900, Brazil;

6. Department of Urbanism and Environment, Federal University of Rio de Janeiro, Rio de Janeiro, 21941-901, Brazil;

7. Department of Design, Representation and Technology, Federal University of Juiz de Fora, Juiz de Fora, 36036-900, Brazil;

8. Department of Design, History and Theory, Federal University of Juiz de Fora, Juiz de Fora, 36036-900, Brazil

\begin{abstract}
This paper aims to discuss how the shaping of a city, Juiz de Fora, in Brazil, has resulted from the power of location of some social agents and from their disputes on the production of space. First, it introduces the concept of social production of space, emphasizing the role of social agents in urban processes. Then, it presents specific aspects of the history of Juiz de Fora: its origins and how social agents and forces have played a significant role in shaping the built environment of the city — specially represented by main streets of the city. The paper studies how the social agents, with their different visions and goals, have influenced the process of formation and development of the city. This demonstrates the complexity of the existing relationships between the built environment and the social context that is specific to the city. Different urban forces fight for city spaces, construct and modify its territory so that their needs are fulfilled. Their strength, their experiences and efforts, and their ideas of a city are inscribed in urban landscapes; in similar ways, these are revealed by the city paths we follow here.
\end{abstract}

Key words: Social production of space, social agents, social site, constructed environment, urban history.

\section{Introduction}

A major contribution of geography to urban studies is the acknowledgement of Henri Lefebvre's concept of "social production of space"; that is, the perception that space is not just a construction of nature, but also a "consequence of the action of concrete, historical social agents endowed with interests, strategies and spatial practices of their own, carriers of contradictions and creators of conflicts among themselves and with other segments of society" [1].

However, there is a contradiction which is central to this process. Space is socially produced, for instance,

Corresonding author: Victor Nascimento, master in built environment, research fields: design, history, theory and urban planning. E-mail: victorhugodoy@gmail.com. by agents of the public sphere, as the State, real estate developers and excluded social groups. Despite this, urban space is generally privately owned. Therefore, urban space is a commodity and, the access to it is unequal between social classes. This condition directly affects the constant process of production of space [2].

By means of this contradiction, it is necessary to study the different forces that act in the formation of cities and understand them as complex objects. Hence, the aim of this paper is to relate the dispute by the locating power in the city and the decision-making between social agents that produce urban space. First, a critical look is taken at the processes of social production of urban space, highlighting the importance of social agents that produce the constructed 
environment. Then it is done a brief history about the origins of the city of Juiz de Fora, emphasizing some agents and forces that played a significant role in shaping the city's current constructed environment, specially the one represented by important streets.

\section{Social Production of Space}

"Urban land is a highly and sophisticatedly crafted natural material, such as planes or electronic devices are. The expressions 'built environment' and 'social production of space' have disseminated the comprehension that urban space is not a free gift from nature, but rather a produced social product, and the result of social work" [3].

The notion of social production of space conveys important issues: its sense reveals the contents of the production process, the producers' subjects, the agents of material production of space, the purposes that guide this production set in a society as well as the ways it is appropriate. From this perspective, man places himself in the center of the discussion of the space as a subject.

As a production of social agents, space is impregnated in materiality, such as roads, dams and urban centers with streets, neighborhoods, commercial and industrial areas, but also full of many meanings, such as those associated with aesthetics, status, ethnicity and sacredness [1].

According to Souza [4], those we might call the "spatial professions", that is, professions concerned with the study of social spatiality or planning interventions in space (notably geography, urbanism and urban planning in general), have traditionally represented an approach synthesizable by the expression "overflight vision". To consider societies and their spaces from an "overflight vision" involves analyzing them "from above" and "at a distance". Essentially, it means to emulate or to adopt the typical perspective of the State apparatus.

Castells [5] points out that "social actors produce cities and urban meanings". Thus, one of the questions is: "How these actors produce and reproduce cities through their conflicts, dominations, alliances and commitments?" To answer this, he argues that class relations, the autonomous role of the State, gender relations, ethnic, national movements and also the movements of citizens are important sources of social change.

The forms of cities reflect their social organizations, political and economic structures and, even, the way of life of its inhabitants. Similarly, the needs and desires of the population, the political and economic decisions contribute to design and build the morphology of cities. Thus, as it is being constantly transformed, the morphology of cities is not static, but historical.

Each city has its own history, involving several effects of the action of social agents, especially those protagonists with regard to the power of decision-making on shaping the city over time.

\section{Social Site and Decision-Making}

Urban space is a peculiar product of human labor. It is a result from the production of values by workers and owners of the means of production: buildings, streets, networks, and squares. The urban space, however, has its own value that should not be mistaken either with the value of these products or with their sum; it is the value of the location. As a social construction, the location is the element that most influences the value of city spaces and, therefore, in real estate speculation.

According to Santos [6], speculation derives, ultimately, from the combination of two convergent movements: the superposition of a social site to a natural site and the dispute between activities and people for a given location. Social sites are created, since the functioning of urban society selectively transforms places, adjusting them to their functional requirements. That is how some points become more accessible, as well as some arteries become more attractive and, some others, most valued. Thus, more dynamic activities are installed in these privileged areas; regarding places of residence, the logic is the same, with wealthy people seeking to stay where it 
seems most convenient to them, according to the canons of each epoch, which also includes fashion. This is how the various parts of the city gain or lose value over time.

The social site, is defined by Santos as a social construction. However, there is a constant struggle between activities and people for the appropriation of a given location, as urban space is a source of income. And since the higher classes tend to be located in the same region of the city [3], this happens to be the location that receives more investment from both the private power, aiming at the reproduction of capital, and the public, due to the increased political power of the wealthier classes [5].

\section{Juiz de Fora and Its Constructed Environment}

The origins of the city of Juiz de Fora go back to the opening of the New Path in 1711, a road that connected the gold mining region of Minas Gerais to the Guanabara State with a journey time of 15 days. The New Path served for around 200 years as an artery for the transportation of goods and commodities between the port of Rio de Janeiro and the state of Minas Gerais.

With the fall of mining in the second half of the 18th century and the rise of the coffee economy, the New Path went on to serve mainly to transport food goods, especially coffee. At this time, the Portuguese began to distribute land — for people of noble birth — called land grants, facilitating the settlement and the formation of farms. Among these farms was the Juiz de Fora's (literally "judge from the outside", an existing job at that time) farm, which later became the name of the city that would arise there [7].

In 1830, the government decided to transform the tortuous, century-old, slippery path into a good, navigable road, compatible with needs. A German engineer, called Heinrich Wilhelm Ferdinand Halfeld, led the construction of the new road in 1836. The Paraibuna's Road actually consisted of a series of modifications to the original layout of the New Path.

\subsection{Halfeld's Road and the Consolidation of Urban Center}

According to Gama [7], when Halfeld modified a part of the previous route emerged in "the gracious hill later called Alto dos Passos", the town of Santo Antonio do Paraibuna, which in 1856 was elevated to city status. Lessa [8] said that according to oral tradition, the engineer commented, after carefully observing the $5,000 \mathrm{~m}$ long and 2,000 m wide floodplain that fascinated him: "Nice place to build a city!". Indeed, in that place, he built that stretch of the Paraibuna's Road, which eventually became known as New Road, then Right Street and finally Rio Branco Avenue, the main axis of the city of Juiz de Fora.

Coming from Barbacena (a city near from Juiz de Fora), after reaching current Benfica neighborhood, Halfeld crossed the Paraibuna River, paving the way for its right margin. To escape from the marshes, he went up the current Gloria's Hill, setting Andradas's avenue, skirted the vast pond of $50,000 \mathrm{~m}^{2}$ that existed in the Riachuelo' square location and, on an impressive straight of about 3,000 m, went up to the Alto dos Passos neighborhood [8].

The route made by Halfeld was crucial to the development of the village. As Passaglia [9] states, the rectification made by him in 1836, already had an explicit intention that there would be a built city. In fact, since the late 19th century and early 20th century, much of the urban life of the city was focused on the banks of the future avenue, as the Mother Church, the Municipal Offices, the main square of the city (future Halfeld Park) and most of the small palaces that housed the coffee and industrial elites [10]. This centralized axis condition led Genovez [11] call it "the soul of the city".

We also emphasize that the current Rio Branco Avenue was the place where many improvements towards the beautification of the city started, not only for its functionality and scale, but also because it houses the headquarters of the Municipal Offices, the Main Church and the mansions of the most influential families of the city's elite [7]. 
In the first decades of the 20th century, we had major incentives to vertical integration that influenced decisively the constructed environment of the avenue, such as the prohibition of one-floor buildings in the central streets and tax exemptions for those over two floors [7].

Over time, many investments were made along this axis: paving, sidewalks, infrastructure, lighting, public transport, among others. Consequently, the land and buildings located there were constantly being valued. In the early 20th century, major coffee producers and industry owners' houses already occupied much of the land. By the 1960s and 1970s, the avenue was becoming denser as it extended in height, with vertical elevations. Nowadays, with a central lane exclusively for buses, the two-way avenue represents the most majestic street in the city, and experiences considerable movement of people and vehicles [12].

Halfeld was part of a generation of "pioneers", worshiped to this day, which helped plan and organized the space of the future urban center of Juiz de Fora. Reports on the construction of the city, which appear more than five decades later, are characterized by laudatory tone and strengthen the heroic myth of occupation of the territory [13].

The most curious is that more than half of the city's population in 1855-precisely 16,482 inhabitants - were slaves, not to mention that the social groups of free citizens included browns and freed slaves, which means a very small number of white people. Nevertheless, in reports about the formation of the city, written years later by journalists and researchers, there are very few references to black people's habits or their main collaborations-notoriously excluded from "official" narratives [14]. Therefore, their effective role in the shaping of the city, beyond manual labor, remains disregarded.

\subsection{Procopio's Road to a New Centrality}

Juiz de Fora gradually becomes a place that attracts investments of an emerging bourgeoisie. As is the case of Mariano Procopio Ferreira Lage, who makes a concession to build and operate the services of another new road. Fascinated by new technologies, he had known in Europe and the United States, Procopio has built in Juiz de Fora the most modern highway in South America: the Union and Industry Road.

Returning to Brazil, Mariano Procopio has organized the Union \& Industry Company, responsible for the construction of the road. In 1858, the first German settlers arrived in the city contracted by Procopio to build the roadway. As Passaglia [9] reports, "farmers and craftsmen-workers formed an immigrated group to Juiz de Fora, which decisively influenced to incorporate habits and life goals different from the ones of the dominant tradition, contributing to the provincial town would not be impregnated only by a patriarchal agrarian system".

In some sections of the Union and Industry Road, Procopio took the route of Paraibuna's Road, as well as Halfeld did when he drew the latter on the New Way. Upon reaching Juiz de Fora, however, Mariano Procopio made significant changes in its route. He has abandoned the stretch of the old road in the current Graminha district area, to make way for the current Poço Rico neighborhood. This change generated several complaints because it would lead to the abandonment of the Alto dos Passos, which was embraced by Halfeld's road and turned into the initial core of the city's settlements.

Another significant change in the course of Union and Industry Road regarding Paraibuna's Road was the insulation of the huge straight traced by Halfeld, location where the city was developing with greater expressiveness. "Mariano, with what appeared to be an intention to marginalize the city (...) when get to the Riachuelo's square (...) despite vehement protests, twisted the direction of the road to the east at an 45 degrees angle and took the straight ahead for a thousand meters-setting the current Getulio Vargas Avenue - up to the point where today this avenue 
meets the Holy Spirit Street (...). That is what modern road technique currently practices: the outline of urban perimeters. But at that time was death by isolation" [8].

Starting from the junction of this road with the old one, the path of Mariano Procopio was heading to the west, bordering the Paraibuna River and moving away from the city center. Union and Industry Road meant to Juiz de Fora the beginning of a new stage in its development. It also brought important changes in the very mentality of the time, with its dynamism and sense of modernity.

Giroletti [15] shows that besides facilitating the flow of coffee production, the highway has enabled the city to become a real trading post, "as the terminal point of the most important means of communication of the Province, Juiz de Fora becomes the place of major passage between Minas and Rio de Janeiro states, the most dynamic economic core of Zona da Mata and polarizing a vast region of Minas and part of Goiás”.

Economic growth is reflected in the urbanization process and in the tax collection. If in 1861 Juiz de Fora was already the third collector municipality in the province, before 1870, it had become the main collector municipality of Minas Gerais [15].

Cid [16] argues that the late 19th century and early 20th century were a period of "an absolutely authentic example of private enterprise" which occurred by the conjunction of several factors: the country's best road, which allowed the flow and the conquest of markets and the attraction of wealth; the social structure with European experience that has evolved from the Union and Industry Road for the first mechanical and beverages companies; the ability to act and making without the intervention of the State and the existence of an entrepreneurial elite, who has come from the coffee industry.

For Oliveira [17], besides all these motives, there were other factors that made Juiz de Fora a great hub of attraction of investments: "The city grew. Its population gained another look. That rural people from urbs assumed the appearance of a commercial and industrial town. They built up public buildings, the appearance of the private constructions improved, the phone communications arrived, as well as the trams pulled by donkeys, secondary schools were multiplied and a few colleges appeared, sanitation was done, the government introduced improvements, just to mention a few advances. In 1877, there were 872 residential houses, which authorize to estimate a population of about 5,000 inhabitants. In 1885 , this population has risen to 17,622 inhabitants. Cultural activities were developed, newspapers proliferated".

From all that has been said before and in accordance with Abdalla [18], we can say that at this time the city of Juiz de Fora was conceived within an ideology of modernization sustained by coffee barons through industrial and financial investments. Thus, the city sought an image consistent with the parameters of the modernity of major metropolis.

\section{Final Considerations}

Urban space should be seen as a historic resulting product of the mode of production and the political system, and is, thus, a witness of time. It works as a memory of the constructed environment and objects set in the preterit landscapes.

Society produces the space and, in doing so, reveals a contradiction, as already has noted above, from a production process, which is socialized, and the ownership of space, which is private.

The study of the different actors, with different visions and goals that influenced the process of formation and development of the city, demonstrates the complexity of relationships that exist between the constructed environment and social context that allows the achievement of this specific shape of the city. Urban forces that construct and modify the space attend to meeting their needs, fighting for the city space, but also demonstrating an idea of the city that they wanted to build and expose the experiences of strengths and efforts inscribed in urban landscape, as the paths that were seen here help to reveal. 


\section{Acknowledgments}

The authors would like to thank to Federal University of Juiz de Fora (UFJF) to support this publication.

\section{References}

[1] Corrêa, R. L. 2012. "Sobre Agentes Sociais, Escala e Produção do Espaço: um Texto para Discussão." In $A$ Produção do Espaço Urbano: Agentes e Processos, Escalas e Desafios, edited by Carlos, A. F. A., Souza, M. L., and Sposito, M. E. B. São Paulo: Contexto. (in Portuguese)

[2] Lefebvre, H. 1999. A Revolução Urbana. Belo Horizonte: UFMG. (in Portuguese)

[3] Villaça, F. 2001. O Espaço Intra-Urbano no Brasil. São Paulo: Studio Nobel/FAPESP. (in Portuguese)

[4] Souza, M. L. 2007. "Da 'Diferenciação de Áreas' à 'Diferenciação Socioespacial': A 'Visão (Apenas) de Sobrevoo' como uma Tradição Epistemológica e Metodológica Limitante." Cidades 4-6: 101-14. (in Portuguese)

[5] Castells, M. 1983. A Questão Urbana. Rio de Janeiro: Paz e Terra, 17-20. (in Portuguese)

[6] Santos, M. 1993. A Urbanização Brasileira. São Paulo: Hucitec. (in Portuguese)

[7] Oliveira, P. 1966. História de Juiz de Fora. Juiz de Fora: Funalfa. (in Portuguese)

[8] Lessa, J. 1985. Juiz de Fora e seus Pioneiros. Juiz de Fora: Funalfa. (in Portuguese)

[9] Passaglia, L. A. P. 1982. A Preservação do Patrimônio
Histórico de Juiz de Fora: Medidas Iniciais, Juiz de Fora: Prefeitura Municipal de Juiz de Fora. (in Portuguese)

[10] Almeida, F. A. 2012. "Narrativas Preservacionistas na Cidade: A Trajetória da Defesa do Patrimônio Histórico Através de Manifestações Populares na Década de 1980." M.Sc. dissertation, UFJF. (in Portuguese)

[11] Genovez, P. F. 1998. Núcleo Histórico da Avenida Barão do Rio Branco (Alto dos Passos): Nota Prévia de Pesquisa. Juiz de Fora: Clio Edições Eletrônicas. (in Portuguese)

[12] Tasca, L., Colchete Filho, A. F., and Nascimento, V. H. G. 2013. "Joining Paths and Dividing Paths: Juiz de Fora, Brazil." Journal of Civil Engineering and Architecture 7 (9): 1157-63.

[13] Musse, C. F. 2008. "Imprensa, Cultura e Imaginário Urbano: Exercício de Memória Sobre os anos 60-70 em Juiz de Fora.” Dr. thesis, UFRJ. (in Portuguese)

[14] Fazolatto, D. 2001. Juiz de Fora: Imagens do Passado. Juiz de Fora: Funalfa. (in Portuguese)

[15] Giroletti, D. 1988. Industrialização de Juiz de Fora: 1850/1930. Juiz de Fora: EDUFJF. (in Portuguese)

[16] Cid, W. 1987. "Visão da Imprensa Sobre o Processo de Desenvolvimento." In História econômica de Juiz de Fora (subsidios), edited by Bastos, W. L. Juiz de Fora: Instituto Histórico e Geográfico. (in Portuguese)

[17] Oliveira, P. 1987. "O Advento da Energia Elétrica em Juiz de Fora." In História Econômica de Juiz de Fora (Subsídios), edited by Bastos, W. L. Juiz de Fora: Instituto Histórico e Geográfico. (in Portuguese)

[18] Abdalla, J. G. F. 2000. "Evolução Urbana de uma Cidade Industrial Desde o Século XIX." Presented at VI Seminário de História da Cidade e do Urbanismo, Natal. (in Portuguese) 